\title{
REVIEWS AND NOTICES OF BOOKS.
}

\section{THE FOUNDER OF OPEN-AIR TREATMENT. ${ }^{1}$}

George Bodington's "Essay on Consumption" has now been reprinted in the original type and binding by the author's grandson, who writes a short preface and adds a very pleasing portrait of his illustrious ancestor, which we are here enabled to reproduce. This essay, written " in a

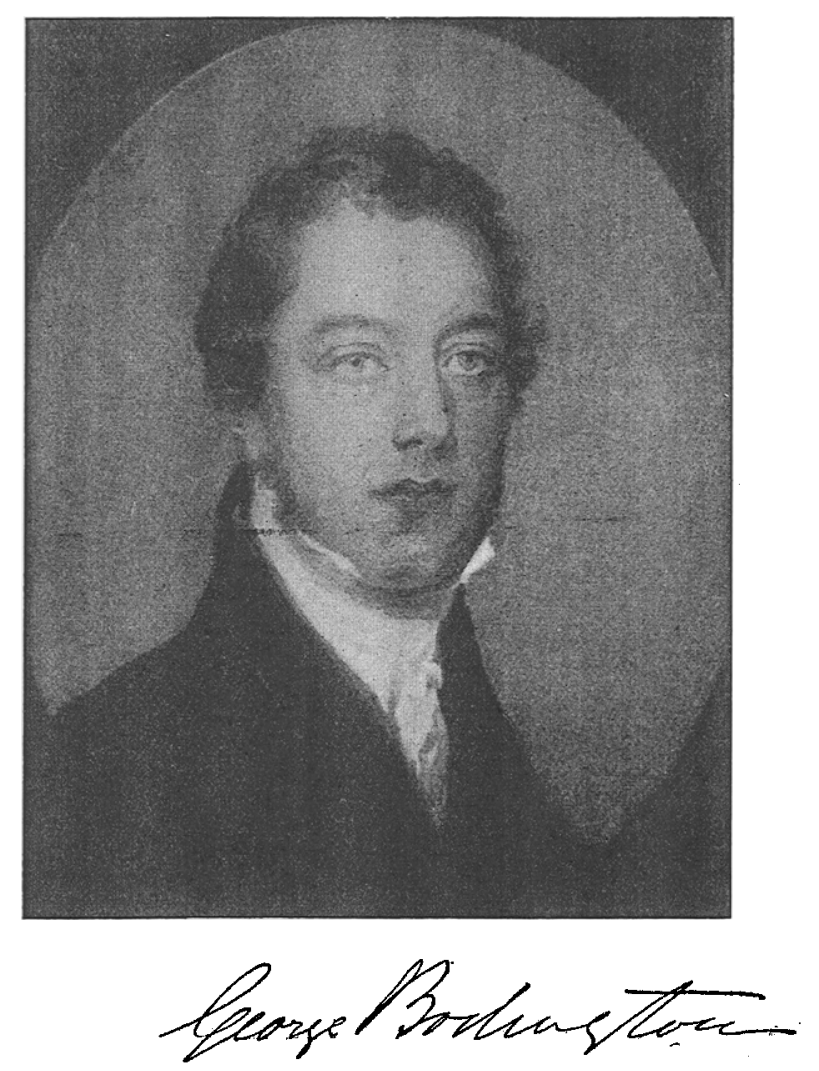

somewhat hurried manner, when short intervals of time could be snatched from occupations varied and almost incessant," yet gives, as Bodington justly boasts, "the pith and substance of the matter treated on "; and we may fairly say that his therapentic recommendations are soundly based upon the truths discovered by his scientific penetration.

I "An Essay on the Treatment and Cure of Pulmonary Consumption." By George Bodington. London: Longmans. I840. Reprinted, with a preface by Dr. Arthur E. Bodington. London: Simpkin, Marshall, Hamilton, Kent, and Co. I906. 
Bodington saw that the course of pulmonary tuberculosis was, in the main, that of an inflammation running on to necrosis. Knowing from Majendie's experiment on the eye, that inflammation and necrosis readily follow a gross injury to the nerve-supply of that organ, he inferred that the necrosis of the tuberculous lung was probably neuropathic. Hence he vigorously denounced lowering treatment, and recommended an open-air life, generous diet, plentiful rest, and carefully graduated exercise. No better theory was possible till Koch's discovery of the tubercle Wacillus in the year of Bodington's death, or, at any rate, till Villemin's clear prophecy that such a germ was to be found for the searching. Even to-day it is not easy to point to any cardinal improvement on Bodington's treatment, except in the matter of the disposal of the sputum. Bodington's scientific acumen was, indeed, splendidly sound and penetrating; but the cases reported by him-only six - are too few in number to bear the weight of his theory. Judged also by the high standard of his day, Bodington's cases are too scantily reported. Bodington's view was undoubtedly too optimistic, and the battle with tuberculosis is much more severe than he knew.

We may wish, however fruitlessly, that Bodington's work had been better appreciated during his lifetime, and that, in particular, his noble enterprise of establishing, in 1840 , the first open-air sanatorium in the world, had been supported by the public and the medical profession sufficiently well to ensure its continuance. But he had some anticipation of the world's tardy justice when in 1866 he wrote to his son: "I often think that, when I am dead and buried, perhaps the profession will be more disposed to do me some justice than whilst I live."

Charles Gaskell Higginson, M.A., L.R.C.P.

\section{PIONEERS OF “ OPEN-AIR " TREATMENT."}

It is always interesting and instructive to study the inception of original work which has stood the test of time, and from reading this clear and careful little appreciation of British pioneers of the socalled "open-air" treatment of pulmonary tuberculosis, one may derive both pleasure and profit. Bodington's wonderful intuition -of which he showed, if only for a short time, the practical outcome in a form which all the world is adopting more than fifty years later-is rightly rated above the more controversial methods of MacCormac; but one feels more than ever "the pity of it " (to fall in with Dr. Higginson's quoting humour), that, as he says, the two men missed each other. The course of the comparative analysis is enlivened by many allusions and references. They are of somewhat unequal importance and pertinence, but serve to give the whole a not unpleasing literary flavour.

Dr. Higginson wonders to find a man of MacCormac's calibre "helplessly subjected to his weak theory of Carbohæmia.". A sentence or two below he qualifies this by citing a similar trait of Priestley. Is it not rather common in scientific discoverers? Fechner's now forgotten pan-animistic enthusiasms, for instance, led him to face the labour of founding the science of psycho-physics. And there are more recent examples. W. C. Rivers, M.R.C.S.

1 "The Cure of Consumption, according to George Bodington and Henry MacCormac." By Charles Gaskell Higginson, M.A., L.R.C.P. (Lond.). Reprinted from Birmingham Medical Review, January, 1905. Pp. 28. Birmingham: Percival Jones, I905. 